\title{
Xylogenesis, photosynthesis and respiration of Scots pine trees growing in Eastern Siberia (Russia)
}

Antonova Galina Feodosievna ( $\sim$ antonova_cell@mail.ru )

VN Sukachev Institute of Forest SB RAS

Stasova Victoria Victorovna

VN Sukachev Institute of Forest, SB RAS

Suvorova Galina Georgievna

Siberian Institute of Physiology and Biochemistry of Plants, SB RAS

Oskolkov Vladimir Alekcandrovich

Siberian Institute of Physiology and Biochemistry of Plants, SB RAS

\section{Research Article}

Keywords: Pinus sylvestris L., cambium activity, biomass, photosynthesis, respiration, temperature, precipitation

Posted Date: July 20th, 2021

DOI: https://doi.org/10.21203/rs.3.rs-470664/v1

License: () (1) This work is licensed under a Creative Commons Attribution 4.0 International License. Read Full License 


\section{Abstract}

Key message The relationships between cambium activity, cell wall biomass accumulation and photosynthesis/ respiration in Scots pine trees, growing in Eastern Siberia (Russia), change during the season in dependence on combination of summer-weather conditions.

The wood formation in tree trunks depends on photosynthesis and respiration and the each of the processes are under the effect of external factors. Each factor effects the growth in combination with other factors and the change in any of these factors leads to strengthen or to weaken of the growth processes in tree. We investigated the formation of xylem and phloem cells by cambium, cell wall biomass accumulation in Scots pine trees, growing in Eastern Siberia (Russia), in dependence on the productivity of photosynthesis and energy cost in separate seasonal periods in the years with opposite summer-weather conditions. The cores extracted throughout 10-day from the stems of 10 trees during the seasons were used to determine the number of cells with different development degree and their morphological parameters. Cambium activity and cell wall biomass accumulated on the separate stages of annual ring wood formation and their connections with the photosynthetic productivity of crown and the level of stem respiration photosynthesis were assessed. The activity of cambial cell division into xylem or phloem sides in separate periods depended on the combination of temperature/precipitation and on the connection with photosynthesis and respiration. The dynamics of biomass accumulation was bimodal with the maximums in June (earlywood development) and mainly in August (development of thick-wall late tracheids), what was due to the combination of optimal temperature and the moisture in the stem tissues. The variation in the external factors changed the balance between the incoming of photoassimilates and the energy cost causing a competition for photosynthesis products and, as a consequence, photoassimilates were used not only for cell-wall biomass synthesis and but also for their reservation of spare substances in the form of starch. The data is useful to understanding of internal processes of wood annual ring formation in pine trees.

\section{Introduction}

Productivity of woody plants, their growth and annual ring biomass accumulation depends on carbon balance of photosynthesis products and their expenditure on respiration, associated with the growth of both new formed and the maintenance of living organs and tissues in the stem. The changes in carbon balance under external factors must influence radically on biosynthesis of cell wall structural components, growth and development cells, and, finally, on the amount of biomass deposited during vegetation.

The impact of temperature and water stress on photosynthesis and respiration of growing trees was the subject of studying by (Gordon and Larson 1968; Zagirova and Kuzin 1998; Bolondincki and Kaybijanen 2003; Deslauriers and Morin 2005; Gruber et al. 2009; Begum et al. 2013; Deslauriers et al. 2014; Suvorova 2009; Alam et al. 2017; Chan et al. 2018). The respiration of assimilating and non-assimilating of tree parts was also studied (Gifford 2003, 2000; Molchanov et al. 2011; Zabuga and Zabuga 2013, 2014; Chan et al. 2018). In the stands, where the mass of non-assimilating organs was relatively high, the proportion of carbon expended on maintenance respiration as well as on growth respiration has considered by (Ryan 1990, 2011; Ryan et al. 1992; Maier et al. 1998; Makela and Valentine 2001; Gifford 2003; Tselniker and Molchanov 2005). To find the connection between tree growth productivity and the respiratory cost in the season such indexes as tree stem diameter and radial increment width on the cores, extracted from tree stem (Ryan 1990; Lavigne et al. 2004; Zha et al. 2004; Acosta et al. 2008; Chan et al. 2018), the volume of sapwood living cells (Ryan, 1990), the number of differentiating cells of xylem (Lavigne et al. 2004; Gruber et al. 2009; Zabuga and Zabuga 2013) and the weight of seedlings or vegetative organs (Zabuga and Zabuga 2006, 2014) were used..

However, the number of differentiating cells, stem radial diameter, radial increment width don't shows the real biomass accumulated within wood rings during the season. The biomass, deposited in branches and stem, is the result of the growth of cells, produced by cambium, at successive stages of primary cell wall development and substance accumulation within tracheid walls during secondary wall thickening. All these processes depend on supplying of the substrates coming from photosynthesis and on the energy due to respiration, which in turn are under the effect of temperature and moisture availability. In conifers the biomass is concluded in the walls of earlywood and latewood of cells, differing in radial diameter and thickness walls. Their formation and development during the growth season occur separately in the time and the space and the each of growth processes reacts on external factors by differently consistent with physiological cell state and biochemical reactions in cells (Antonova and Stasova 1993, 2015). The influence of external factors on secondary wall thickening of earlywood cells and the growth by expansion of latewood tracheids, which overlap each other in the time (usually in July), is dissimilar (Antonova et al. 2015). Obviously, that the demand for the products of photosynthesis (assimilates) for creating the cell walls structure and the cost of respiration (flux of C02) must also be different. It should expect the changes not only in total respiration, in growth respiration and maintenance respiration, but also in the relationship of respiration and photosynthesis in dependence on external conditions and wood cell development degree. Denne (1970) supposed there is independent influence of the ambient conditions on the stages of xylogenesis. The understanding of cellular processes under the temperature control and the contribution of photosynthesis in them is necessary for better mechanistic understanding of tree growth (Ryan 2011). General phenological observations of xylem tissue formation in Northern Hemisphere forests showed different sensitivity of xylem ring size and woody biomass production to climatic factors and the presence of the time lags in boreal, temperate, sub-alpine and Mediterranean forests (Cuny et al. 2015).

Phloem living cell volume as transport network supplying carbohydrates from photosynthesis and/or storage tissues (sources) to the areas of active growth and metabolism (sinks) can also influence the stem respiration cost (Savage et al. 2015). Their volume increases at high latitudes because the products of photosynthesis, unused wholly on the formation of morphological xylem structure in light conditions and lower temperature, keep in phloem cells. In the stems of Norway spruce trees growing in northern Sweden 75 and $80 \%$ of the living cell volume in the stems was in the phloem (Stockfors and Linder 1998 ). The amount of the living cells in the phloem in the stems of 200 -year-old Scots pine trees, growing in Russia $\left(60^{\circ} \mathrm{N}, 89^{\circ} \mathrm{E}\right)$, was $55-69 \%$ from the total volume and depended on the period vegetation and diameter growth rate (Astrahantseva and Antonova 2011).

The deposition of biomass in the walls of earlywood and latewood tracheids during development of annual wood ring into the stem of Scots pine trees growing in Eastern Siberia and the connection of these processes with the photosynthetic productivity of the crown and respiratory expenditures under the 
effect of temperature and moisture accessibility were studied earlier for 1999 year (Suvorova et al. 2015; Antonova et al. 2017). Climatic conditions of the region are very contrasting and in summer time, when the main growth processes take place, precipitation and temperature can vary greatly in separate periods of the vegetation. In the season of 2001 year compared with 1999 year, very high temperature in June and unusually high rainfall precipitation in July were observed. For better understanding the relationship between cambium activity, cell wall xylem development and photosynthesis and respiration it is necessary to determine the dynamics of these processes in separate periods of the seasons with different summer-weather conditions.

The object of the study was to: (i) estimate the cambium activity and biomass deposition in the stems of Pinus sy/vestris L. and the relationship of the processes with photosynthetic activity of crown and stem respiration in separate season periods of 2001 year, (ii) compare and analyze the reasons for the difference in the biomass accumulation in the dependence on photosynthesis activity and respiration during annual wood ring formation in opposite summerweather conditions of 1999 and 2001 years.

\section{Materials And Methods}

Annual wood layer formation in Pinus sylvestris L. was monitored on 10-12 in 25-year-old trees growing in artificial stand located from 80 km from southwestern coast of Baykal (Russia).

The cores were extracted by special punch (diameter $0.8 \mathrm{~cm}$ ) from pine stems every 8-11 days at the height approximately $1.3 \mathrm{~m}$ over ground, avoiding the ringing of stem, during the seasons of 1999 and 2001 years. Immediately after the extraction, the cores $(1.5 \times 0.8 \mathrm{~cm})$ were fixed in mixture of acetic acidformaldehyde-ethanol (5:5:90) (Antonova and Stasova 1993). At the cross-sections of the cores, stained with water solution of $0.05 \%$ cresyl-violet (Antonova and Shebeko 1981), the numbers of the cells in 4-5 radial rows of annual wood layers of two previous seasons were calculated. The trees, in which the number of cells in radial rows was described by Gaussian curve, were used for further observations. Such the selection of the trees minimizes the standard deviations from the average values since the selected trees have identical reaction on the ambient conditions. The method of tree's selection was used earlier in our investigations (Antonova and Stasova 1993, 1997).

Two cross-sections of the each core extracted from 10 trees were used to count the number of cells of phloem and xylem in the zones of growth expansion and secondary wall thickening in 8-10 radial rows (3-4 rows of the each core) of tracheids with large radial diameters. Tracheids with the larger radial diameters reflect real growth processes because fusiform cells (tracheids) during intrusive growth penetrate between the ends of other cells and the cells with narrow radial diameters can be present on cross sections. The number of cells in cambial zone, newly formed phloem cells and xylem cells in the zones of growth expansion, secondary wall thickening and mature xylem were counted. The radial and tangential sizes of tracheids and their lumens on each development stage were measured. The average number of the measurements comprised $70-80$ (10 trees, 2 cross-sections of the each core, $3-4$ rows of tracheids).

The cambium activity in the each period was evaluated by the number of cambial initial divisions into the side of xylem or phloem using the observations of Mahmood (1971), according to which one division of cambial initial cell gives two mother xylem cells, which in turn produces four cells of xylem tissue. In contrast, one division of cambial initial cell into the phloem side gives two phloem cells. The radial and tangential sizes of tracheids in secondary wall thickening zone were measured to calculate cell wall cross-section areas, which was considered as the biomass, accumulated in cell walls. This index for estimating of the biomass, accumulated in cell walls of the annual wood increment, was used in our work earlier (Antonova and Stasova 1993). The difference between cell wall cross-section areas in subsequent and preceding periods means the biomass deposited per the each period in the season.

The absorption of carbon dioxide by the stem crown and the respiration activity of the stems were recorded on 10-year-old trees of Pinus silvestris L. growing in the artificial stand, deposited just near the first stand.

The measurements of $\mathrm{CO}_{2}$-absorption were recorded on 2-year shoots 3-4 days in the each week. The respiratory activity of the stem was recorded at a height of 1.3 m over 24 hours by multi-channel device mounted on the basis of INFRARED gas Analyzer-"Infralyt-4" (Shcherbatyuk 1990). The data on photosynthesis, recorded per the each daytime hour, summarized per the day of the each period and then per the period. The stem respiration was recorded the each hour over 24 hours. All data were summarized per daytime and nighttime in the each period, per the day of the each period and then per the period. All data were normalized to $10^{\circ} \mathrm{C}$.

The air temperature and precipitations were recorded every hour. The temperature and precipitation were calculated as the average for the period. The relationship of the components of production process (biomass accumulation, the activities of photosynthesis and respiration) with the weather conditions of the each period in the season was analyzed by regression analysis with statistical computer software (MS Excel).

\section{Results And Discussion}

\section{Cambium activity and weather conditions}

The seasons of 2001 and 1999 years were considerably differed by temperature and precipitations from the average data for region weather conditions and, in particularly, by summer-weather conditions. In 2001 year the high temperature was noted in June (daytime was up to $30^{\circ} \mathrm{C}$ ) and low temperature in July. The average monthly temperature in June 2001 was higher by $4^{\circ} \mathrm{C}$ and in July was less than by $1.5^{\circ} \mathrm{C}$ in comparison with 1999 year. Furthermore, abundant precipitation was observed in July $(247 \mathrm{~mm}$ ) and August $(80 \mathrm{~mm})$ of 2001 year against $146 \mathrm{~mm}$ (July) and 49 mm (August) in 1999 year, while average monthly precipitations in June were practically equal (59 and 61). Fig.1 shows the differences in temperature and precipitation in the periods of 1999 and 2001 years. 
Fig 1 The changes in temperature and precipitation in separate periods of 1999 (A) and 2001 (B) years

The cambial activity, assessed by the number of cambial initial cell division into the side of xylem and/or phloem, and biomass accumulation, evaluated by the increment of cell wall cross-section area, in 2001 year are shown in Fig. 2.

Fig. 2 The dynamics of cambial activity as the number of cambium initial cell division into the side of xylem and/or phloem and of the increment of cell wall cross-section area (S increment) in the separate periods of 2001 year

On the Fig. 2 (and further) the production of xylem and phloem cells by cambium are shown with the first decade of June. However, obviously, that the cambium reactivation occurred in the first/second decade of May. At this time mean daytime temperature changed from 8 to $14^{\circ} \mathrm{C}$. Daily temperature above a threshold value of $5^{\circ} \mathrm{C}$ is enough to the outset of cambial activity in $P$. sylvestris (Seo et al. 2008). In conifers such as Larix decidua, Pinus cembra and $P$. abies, cambial activity and xylem differentiation occurred above a certain threshold value of mean daily temperature, which ranged from $5.6 \circ$ to $8.5^{\circ} \mathrm{C}$ (Rossi et al. 2007, 2008). Threshold temperatures appear to differ among species even when trees grow under the same climatic conditions (Begum et al. 2013). According to our observations the optimal day temperature for cambial cell division in Scots pine stem is $18 \circ-20^{\circ} \mathrm{C}$ (Antonova and Stasova 1993,2015 ). The favorable temperature at the beginning-June in 2001 year $\left(17 \circ-18^{\circ} \mathrm{C}\right)$ and the sufficiency of soil moisture, accumulated within the winter-spring period, leaded to the intensive divisions of cambial initials both into the side of xylem and phloem (Fig. 2). The increase in mean daily air temperature up to $\mathrm{T}=21.7^{\circ} \mathrm{C}$ and day temperature to $30^{\circ} \mathrm{C}$ in the second decade of June (Fig. 1) provoked the sharp reduction in the activity of the cambium (Fig. 2). The increase in temperature influences especially negatively on the production of phloem cells. The temperature higher $15^{\circ} \mathrm{C}$ suppresses the division of cambium cells into the side of phloem (Antonova and Stasova 2015; Antonova et al. 2017). The increasing in maximum daytime temperature to $27 \mathrm{o}-29^{\circ} \mathrm{C}$ and significant reduction in precipitation in the last decade of June decreased sharply the production of phloem and xylem cells produced by cambium (Fig. 2). Great number of precipitation at the beginning of July (Fig. 1) stimulated the divisions of initials to the phloem side. The last phloem derivatives of cambium appeared in the middle of August.

Especially active divisions of cambium into the side of xylem occurred in the beginning- June, in July and at the beginning-August in 2001 year, whereas in 1999 year this was observed in June and August. The significant activity of cambium at the beginning-June of 2001 year was due to moderate temperature and moisture sufficiency in the soil, accumulated within the winter-spring period. At the beginning-July, the activity of cambium increased because of the heavy precipitation and the favorable temperature, when daily temperature was not more then $21 \circ-22 \circ \mathrm{C}$. It is important because the temperature $20 \circ-25^{\circ} \mathrm{C}$ is optimal for plasmatic transport (Carr 1976; Gamalei et al. 1996). The favorable combination of the moisture (heavy precipitation of previous and subsequent periods) and optimal temperature in the end-July - the beginning-August of 2001 year leaded to the increase in xylem cells produced by the cambium.

\section{Temperature}

The combination of the factors had the decisive influence on the division of cambial initials into xylem side in the different seasonal periods. On entire season of 2001 year the production of xylem cells by cambium showed the weak positive connection with the temperature $\left(R^{2}=0.25\right.$, $\left.P<0.05\right)$, while in July and August the dependence was rather strong $\left(R^{2}=0.84, P<0.001\right)$. In July, this occurred because of very large precipitation, in August due to lower temperature. In balsam fir in the Québec boreal forest (Canada) the influence of temperature on tracheid production was recorded mainly from the end of May to mid-July during earlywood production (Deslauriers and Morin 2005).

The phloem in comparison with the xylem had negative correlation with temperature. In drought conditions of 1999 year the influence of temperature on the division of cambial initials into phloem side was negative with $R^{2}=0.48$ at $P<0,05$ (Suvorova et al. 2015; Antonova et al. 2017), whereas in the season of 2001 year that was obscure because of the precipitation, especially in July. Smaller dependence of phloem formation on environmental factors and mostly influence by endogenous factors were remarked (Gričar and Čufar 2008; Fajstavr et al. 2020). According to (Fajstavr et al., 2020) the phloem tissue is less sensitive to exogenous factors. In pine stems the initiation of phloem production by cambium occurs at lower temperature compared with xylem cells (Astrakhantseva and Antonova 2011; Swidrak et al. 2014).

The daytime and nighttime temperatures in separate seasonal periods influence the cambial cell division into xylem or phloem sides also differently. According to the correlation coefficients the cambial cells in June were divided mainly into phloem side in nighttime $\left(R^{2}=0.37, P<0.05\right)$, while $x y l e m$ cell production was practically absent $\left(R^{2}=0.015, P<0.05\right)$. In July it was daytime temperature that affects mainly the cambial cells division towards xylem $\left(R^{2}=0.91\right.$ against $R^{2}=0.64$ for phloem cell production). In August, the temperature of the day and especially of the night influenced xylem cell production positively. Obviously, such differences depend on the changes in water reserves within tree tissues, what in turn depends on the air temperature, transpiration and quantity of moisture in tree tissues and soil (Kaybijanen et al. 1981; Schulze et al. 1985; Oberhuber et al. 2015), i.e. from water potential gradient in tree tissues.

\section{Precipitation}

The water gradient potential in tree tissues has decisive significance for cambial cell division and, especially, for xylem cambial derivatives by expansion (Nonami and Bouer 1990; Cosgrove 1997). In the conditions of 2001 year, the division of cambium cells occurred up to mid-August (Fig. 2). The cells, formed by cambium in May and June developed secondary wall thickening in the middle-June and in July, forming early xylem layer (Antonova and Stasova 1993, 2015). The tracheids, produced by cambium during July, passed then the development as latewood tracheids. In Eastern Siberia, especially under the conditions of insufficient moisture, cambium activity is completed, as a rule, at the beginning-middle of August. The precipitation in August and favorable temperature can provoke a renewal of cambial activity and primary cell wall development, what leads to the formation of the cells with large radial diameters, 
i.e. an appearance of the false-rings in annual wood layer. For example, such earlywood-like tracheids were remarked in the latewood zone of Pinus pinea L. annual rings (Balzano et al. 2018).

In June of 2001 year the precipitation positively influenced the division of cambial initial cells into the xylem side $\left(R^{2}=0.34, P<0.05\right)$. In July this connection increased $\left(R^{2}=0.45, P<0.05\right)$ and in August reached yet more high level $\left(R^{2}=0.6, P<0.05\right)$. In last case, the connection was described more adequately by polynomial equation according to which the optimal daily temperature for xylem cell production by cambium is $14-15 \circ \mathrm{C}$ with precipitation in $50-60 \mathrm{~mm}$.

The drought leads to the changes in hydraulic properties of formed wood and the reduction annual ring increment (McDowell 2011; Deslauriers et al. 2014). Strong dependence of radial growth in Pinus sylvestris trees on summer drought was recorded in the forest-steppe ecotones in southern Siberia (Tabakova et al. 2020). Secondary growth in Mediterranean conifer (Pinus pinaster) along a continental-aridity gradient responded mainly to water availability and explained as much as $64.7 \%$ of variance for earlywood growth (Arzac et al., 2018). In dry areas such as the Mediterranean region the drought conditions may arise not only as result from a lack of rainfall but also from high temperature, what leads to vapor pressure deficit (Williams et al. 2012) and, consequently, to water potential change. The drought induces many physiological, biochemical processes in developing plant cells and, as consequence, their morphological changes. Meta-analysis of plant response on water stress showed the increasing in reactive oxygen species (ROS), changes in enzymatic and non-enzymatic antioxidants (Sun et al. 2020). The water availability influences the dynamics and structure of lignin during earlywood and latewood tracheid development (Antonova et al. 2019).

\section{Cambium activity and gas exchange}

\section{Cambium activity and photosynthesis}

The relationship between photosynthesis, total respiration and the production of xylem and phloem cells by cambium in separate seasonal periods in 2001 year are shown in Fig. 3.

Fig. 3 The dynamics of cambial activity as the number of initial cell divisions into the sides of phloem and/or xylem and the changes in photosynthesis and total respiration in separate periods of 2001 year

During the whole season the production of xylem derivatives by the cambium had rather weak positive connection with photosynthesis $\left(R^{2}=0.21, P<0.05\right)$. However, in separate months the relations were different. In June and July it was implicit or negative, while in August the dependence was strengthened significantly $\left(R^{2}=0.42, P<0.05\right)$. Evidently, the connection between photosynthesis and cambial cell division into xylem side depended on both internal and external factors. In June and July, the negative correlation can be because of high daytime temperature, which suppresses photosynthesis. In August the temperature was favorable for photosynthesis but there was other center, requiring assimilates. In that period, the active synthesis of the substances into latewood tracheid secondary walls occurred and there was a tension in the consumption of photoassimilates.

The connection between the division of cambial cells into phloem side and photosynthesis must be positive since phloem cells ensure the transport of the products of photosynthesis. However, straight connection between these indices for whole season was practically absent, although reliable nonlinear dependence was observed $\left(R^{2}=0.32, P<0.05\right)$. As mentioned above the optimal temperature for cambium activity to the side of phloem cells is $15^{\circ} \mathrm{C}($ Antonova and Stasova 2015). In June of 2001 year, especially in the third decade, the connection between photosynthesis and cambial activity into phloem side was negative $\left(R^{2}=0.24, P<0.01\right)$ because of high temperature (Fig. 1B). The same negative connection $\left(R^{2}=0.48, P<0.05\right)$ was observed also in the weather conditions of 1999 year, what depended on moisture accessibility and especially of temperature (Antonova et al. 2017). At the beginning-July in 2001 year, the large precipitation and daytime temperature decrease provided favorable conditions for photosynthesis and accordingly for the division of cambial initials into phloem side (Fig. 3). This leaded to the increase of the number of cells in the transport network and, as consequences, to intensification of the flow of photosynthesis products. In this time the straight reliable positive dependence $\left(R^{2}=0.96, P<0.001\right)$ was between the division of the cambial initials into the phloem side and photosynthesis. Cell division and the growth by expansion require a certain level of water potential (Nonami and Bouer 1990; Cosgrove 1997; Antonova and Stasova 1993, 2015). The direct effect of water potential on turgor-driven cell expansion has recently been showed (Cabon et al. 2020).

All data show the relationship between photosynthesis and xylem/phloem cell production by cambium depends on the combination of temperature and precipitation.

\section{Cambium activity and Respiration}

The data on the respiratory activity in Scots pine tree stem and the dynamics of cambial cell divisions into the side of xylem and/or phloem are shown in Fig. 3.

The total respiration throughout the growing season 2001 year had rather low positive connection $\left(R^{2}=0.12\right.$, $\left.P<0.05\right)$ with initial cambium cell division into xylem side. Positive linear relationship between mean monthly growth respiration in the growing season and diameter growth rate (i.e. cell production by cambium and cell expansion) has been found in Scots pine trees in boreal conditions (Zabuga and Zabuga 1985; Zagirova and Kuzin 1998; Zha et al. 2004). There are different correlation levels between the respiration and cambium activity in the separate seasonal periods, as and in the case with photosynthesis. In June and in July the correlation was negative $\left(R^{2}=0.48, P<0.05\right)$, whereas in August it was positive with $R^{2}=0.78(P<0.001)$. Very strong dependence between the number of living xylem cells and $\mathrm{CO}_{2}$ efflux in August existed in Pinus cembra L. in the Central Austrian Alps although the cambium activity stopped 
(Gruber et al. 2009). In Eastern Siberia conditions, the cambium divisions continued to the end of August (Fig. 2). In this period, secondary wall thickening of latewood tracheids occurred and it lasted until second decade of September. This process in Eastern Siberia usually is completed to this time. The biomass deposition in cell walls of annual wood rings requires significant energy for synthesis of cell wall components. Evidently, that the high level of $\mathrm{CO}_{2}$-efflux in August (Fig. 3) reflects not only respiratory expenditures for xylem cell production by cambium (and radial growth) but mainly for the synthesis of components within late tracheid secondary walls, the thickness of which considerably more than that of earlywood cells.

The relation between the respiration and cambial cell divisions into the phloem side throughout the growing season was slightly positive $\left(R^{2}=0.16, P<0.05\right)$. According to the data of Ryan (1990), the living phloem cells in P. contorta and P. cembra consisted only $7 \%$ of whole stem and did not have significant contribution in $\mathrm{CO}_{2}$ efflux during the growing season. However, in the conditions of cold climate, when the number of phloem cells in annual increment increased as it observed in north territories (Stockfors and Linder 1998; Gričar and Čufar 2008; Astrakhantseva and Antonova 2011) the connection between respiration and phloem cell production by cambium was strengthened.

\section{Biomass deposition of and gas exchange}

\section{Deposition of biomass and photosynthesis}

The basic biomass of annual wood increment is accumulated in secondary walls of tracheids. Primary walls of tracheids, produced by cambium, contain 7-8\% of total biomass accumulated in annual layer of wood during vegetation (Grozdits and Ifju 1984). In the conditions of Eastern Siberia the annual wood ring formation in Scots pine stem lasted from the beginning/middle of May to the end/middle of September with variation of the beginning and finishing in the dependence on air temperature. The deposition of substances in earlywood tracheid walls lasted usually during June to the end-July, while that in latewood tracheid walls lasted from the outset of July to the middle/end-September (Antonova and Stasova 1993, 1997). In the walls of earlywood tracheids, the biomass is less than in the latewood cells that directly depends on the duration of cell development in the zone of cell maturation (Antonova and Stasova 1992, 2015).

In the season of 2001 year the development of early tracheids (growth expansion and secondary wall thickening) occurred from the last decade-May to the end-July, while latewood tracheids from the end-June to the middle-September. The dynamics of biomass accumulation, expressed by increment in tracheids walls cross-section area, and the changes in photosynthesis and respiration in separate growth season periods in 1999 year and 2001 year are shown in Fig. 4.

Fig. 4 Seasonal dynamics of biomass accumulation in tracheid walls (Increment of S cell wall), of photosynthesis activity and total respiration in separate periods of 1999 (A) and 2001 (B) years

The dynamics of biomass accumulation in tracheid walls of the annual layers in Scots pine stem was bimodal with maxima in June and August of 1999 and 2001 years (Fig. 4) in spite of the differences in temperature and humidity conditions in July (Fig. 1). The bimodal biomass deposition was observed during annual wood formation in the stem of Larix sibirica Ldb. (Antonova and Stasova 1997) and it has also been noted by (Qaderi et al. 2019). This is the consequence in the temporary differences in cell wall growth processes during wood formation of conifers in the course of the vegetation (Antonova and Stasova 2015).

The average-monthly indices of photosynthesis for June, July and August in 2001 year were higher in 1.6, 1.5 and 1.1 than in 1999 year. In spite of increased photosynthesis in June of 2001 year S-increment composed only 0.89 from that in 1999 year that was resulted from suppressing growth processes because of very high temperature. In July, the cell wall area increment in annual rings of 2001 year was in 1.82 more than in the same month of 1999 year (8110 $\mu m^{2}$ versus $4456 \mu \mathrm{m}^{2}$ ). The increase in precipitation and, as the result, reduced temperature ensured higher level of synthetic processes during secondary walls development of early tracheids in 2001 year compared with July of 1999 year. In August the biomass deposition in 2001 year consisted of 0.75 from that in 1999 year because of significant precipitation (80.7 and 29.3, correspondingly).

The connection between the biomass increment and photosynthesis in 2001 was negative in June $\left(R^{2}=0.38, P<0.05\right)$ and in July $\left(R^{2}=0.86, P<0.001\right)$ but positive in August $\left(R^{2}=0.93, P<0.001\right)$. In August-September the connection was described more adequate by polynomial curve $\left(R^{2}=0.98, P<0.05\right)$. This point to there is optimal level of photosynthesis, higher of which its products are used probably on other process. In 1999 year the connection of biomass increment with photosynthesis was positive in May-June $\left(R^{2}=0.89, P<0.05\right)$ and in August $\left(R^{2}=0.94, P<0.001\right)$ and negative in July $\left(R^{2}=0.12, P<0.01\right)$.

Although obviously that synthetic processes in the cells depends on the substrates supplied from photosynthesis the relationships between biomass deposition and photosynthesis in different periods of the season are not always clear. This indicates it there is the competition for utilization of photoassimilates in growth processes with the changing in the ambient conditions. In addition, the biomass accumulation depends on a respiration and its constituting as energy components of cellular processes.

\section{Biomass deposition and Respiration}

The dynamics of the general respiration, calculated by the periods of the seasons (Fig. 4), shows specific connection of the growth processes in Scots pine stem.

The biomass accumulation in tracheid secondary walls was associated weakly positively with the respiration $\left(R^{2}=0.14, P<0.05\right)$ for whole season of 2001 year. The same was observed in June $\left(R^{2}=0.13, P<0.05\right)$, whereas in July the relation increased $\left(R^{2}=0.66, P<0.05\right)$. The latter might be because of the 
differences in the activities of physiological processes and their requirements to energy costs. Occurring in July secondary wall thickening of earlywood tracheids requires the energy to synthesize of secondary cell wall substances. On the other hand, earlywood tracheids have lesser cell wall thickness compared with latewood tracheids and the increase in respiration can be the result of another biochemical processes. In August-September, when secondary wall thickening of latewood tracheids occurred the dependence between biomass accumulation and respiration was positive $\left(R^{2}=0.40, P<0.05\right)$.

Slightly reduction in the connection between seasonal course of stem growth, measured by the radial stem diameter, and GPP in Scots pine in the southern boreal zone in late summer compared with the early summer was recorded (Chan et al., 2018). Evidently, the energetic costs were determined not only by cell wall component synthesis within late tracheid walls but also by other processes in tree.

In the season of 1999 year, the relations between the biomass deposition and respiration were others because of the external factors, mainly of the moisture accessibility (Fig. 1A). The connection between the indices for whole season was straight positive with $R^{2}=0.25(P<0.05)$, very high in May-June $\left(R^{2}=0.92\right.$, $P<0.001)$, noticeably decreased in July $\left(R^{2}=0.38, P<0.05\right)$ and again amplified in August-September $\left(R^{2}=0.60, P<0.05\right)$. Especially the strong connection between cell wall substance deposition and respiration in May was probably due to favorable moisture and temperature that ensured all growth processes by photosynthesis products.

The comparison the data of 1999 and 2001 years showed that common respiration in June-1999 year consisted 0.94 from that in June of 2001 year, whereas the secondary cell wall area increment was in 1.12 times more than in that month of 2001 year. The productivity of photosynthesis in this month was in 1.6 times more in 2001 year than in 1999 year. In July of 2001 year the respiration was only in 1.08 higher than in 1999 year, whereas the biomass increment in 2001year was in 1.82 more than in 1999. The productivity of photosynthesis was in 1.46 more than in 1999 year. In August of 1999 year the increment of secondary cell wall area was in 1.3 times more than in that month of 2001 year although productivity of photosynthesis was lower (0.89 from photosynthesis in 2001 year) and the respiration was also lower ( 0.9 from the value of respiration in 2001 year). Significant increasing in cell wall biomass in August of 1999 year as compared with 2001 year means that the photosynthesis products were consumed mainly on this process. The decrease in biomass deposition in August of 2001 year was the result of low activity biochemical processes because of large amount of precipitation (Fig 1). It should expect that growth respiration and maintenance respiration must also change in dependence on variations of external factors in these months.

The data received show the biomass deposition in wood ring cells during the season depends on the fluctuations of photosynthesis (Ph) and respiration ( $\mathrm{R}$ ) relying on the changes in temperature and moisture availability. The changes in the ratio of $\mathrm{Ph} / \mathrm{R}$ in dependence on temperature are shown in Fig. 5.

Fig. 5 Effect of temperature (average on the period) on the ratio of photosynthesis/respiration (Ph/R) in separate periods of $1999(\mathrm{~A})$ and 2001 (B) years

The high ratio $\mathrm{Ph} / \mathrm{R}$ at rather low temperature shows considerable excess of photosynthetic products in comparison with respiration cost at the beginning of the seasonal growth processes (Fig. 5). The increase in the temperature caused the decrease in the ratio, i.e. the expenditure of assimilates for respiration exceeded their receipt from photosynthesis. In contrary, the decline in temperature increased an inflow of photoassimilates and relatively diminished their expenditure for growth processes, as this was at the beginning of June of 1999 year. As the result, the biomass accumulation in cell walls increased (Fig. 4A). In the season of 2001 year due to precipitation in July (see Fig. 1) the effect of temperature on the ratio Ph/R was not considerably pronounced as and during whole season excluding September (Fig. 5B).

The relationship between the biomass accumulation, the substrates for which supplied by photosynthesis, and the expenditure on respiration, as energetic cost of this process, can also be expressed by the ratio of $\mathrm{CO}_{2}$, absorbed during photosynthesis, and $\mathrm{CO}_{2}$, allocated in the course of respiration. The changes in the ratio of photosynthesis/respiration (Ph/R) and biomass increment in tracheid cell walls during the seasons of 1999 and 2001 years are shown in Fig. 6.

Fig. 6 The changes in the ratio of photosynthesis/respiration ( $\mathrm{Ph} / \mathrm{R})$ and in the increment of tracheid cell wall area (S increment) during separate periods of 1999 (A) and 2001 (B) years

Average monthly (June, July, August) values of Ph/R were above in 2001, than in 1999 year and were equal $0.60,0.51$ and 0.46 respectively. The relation of biomass increment in 2001/1999 years in these months comprised accordingly 0.89, 1.82 and 0.75 . This means that the accumulation of cell wall biomass doesn't always follow the ratio Ph/R (Fig. 6, B) and there are other processes in the tree influencing stem respiration and utilizing of photoassimilates.

The maximum biomass deposition occurred in August of both seasons, when major growth processes in the tree was completed, and the basic process requiring substrates in this time was the substance accumulation within secondary walls of late tracheids. Unexpectedly high ratio of Ph/R in July 1999 and rather high level in 2001 in the absence of significant consumption on biomass synthesis indicate that there are other physiological processes, utilizing of photoassimilates. The increasing in Ph/R was also at the beginning of September in 2001 year, when all basic growth processes in trees were completed.

The one of the process may be the synthesis/disintegration of starch in the phloem (rays and parenchyma cells) and xylem (cells of rays and resin duct). The starch, earlier accumulated in xylem ray cells due to the activation of photosynthesis with the beginning of growth season, disintegrated to the end-May - the onset-June. Starch granules in xylem cells can again be appeared in the middle-the end of August, when the main growth process in the trees was completed and photoassimilates can be used not only on secondary thickening of latewood tracheids but also on synthesis of starch as the reserve of substance.

The starch in the structural components of phloem is more mobile. The dynamics in starch content (in the cores) in the cells of the rays and axial parenchyma in phloem during the seasons of 1999 and 2001 years is shown in Fig. 7. 
Fig. 7 Changes in starch content (cores) in the rays and axial parenchyma of phloem during separate periods of 1999 (A) and 2001 (B) years

The comparison of starch depletion in phloem rays in July of 1999 year (Fig. 7A) and unusual increase common respiration at the same time (Fig. 4A) showed that the last might be result of aerobic respiration during complete oxidation of the starch, deposited not only in the cells of the rays but and in axial parenchyma of phloem. The changes in the starch of phloem cells in 2001 year had another character (Fig. 7B) because of the weather conditions. The disappearance of starch granules occurred in axial parenchyma cells and the increase in ray cells to the beginning-July. Because of significant precipitation and the improvement in the conditions for photosynthesis in July, the size of starch granules and their quantity in the ray cells at first decreased, insignificantly increased subsequently, while in axial parenchyma cells gradually increased. This coincides with the decreasing in respiration at the beginning and then increasing in July (Fig. 4). The ratio Ph/R in August of 1999 year was only a little less than in 2001 year (0.043 and 0.046 correspondingly), whereas biomass, deposited in cell walls in August of 2001 year, composed 0.75 from the data in 1999 year. Average-month temperature in August in both seasons was practically equal $(15 \circ \mathrm{C})$, that was close to the optimal for visible photosynthesis of pine (Shcherbatyuk et al. 1990). However, the deposited biomass in this month of 2001 year was less than that in 1999 year. This can be resulted from elevated precipitation (almost in 2.5 times) because the biomass deposition within wall tracheids of both pine and larch decreases if the precipitation is bigger than their optimal amount for that (Antonova and Stasova 1993; 1997). Because of the decrease in biomass accumulation the excess of assimilates were deposited in the form of starch in both phloem cells (Fig. 7B) and in xylem rays. The variations in storage starch granules before the cambium reactivation and during cell differentiation/xylem formation and the increasing in starch toward the end-growth season were noted (Sauter and van Cleve 1994; Sudachkova et al. 2001; Begum et al. 2010, 2013).

Thus, the external factors control the balance between the incoming of photoassimilates and the energy cost. This influences in turn the mass accumulation in xylem cell walls of pine tree and the reserves of carbon in the form of starch as the source of the energy.

\section{Conclusion}

Activity cambium, producing of xylem and phloem cells, biomass accumulation within cell walls in the connection with photosynthesis productivity and stem respiration of Scots pine trees, growing in Eastern Siberia (Russia), were investigated in separate periods of two seasons with contrast summer-weather conditions. We found that the connection degree of cambium activity, producing xylem and phloem cells, with photosynthesis and respiration depended on temperature and precipitation and primarily on their combination in the definite periods of the season. The basic quantity of the biomass in cell walls was accumulated in May-June and, mainly in August, when occurs the development of latewood tracheids with thick cellular walls. In the each of these periods, there are optimal temperatures for both photosynthesis and respiration influencing positively the biomass deposition within cell walls. The balance between the incoming of photoassimilates and the energy cost changes with the variation in external factors leading to the competition for utilization of photosynthesis products and what in turn controls biomass accumulation in cell walls of Scots pine trees. The decrease in the demand to photoassimilates for the biosynthesis of tracheid wall structural components leads to their excess, which is stored in the form of starch as the source of energy for growth processes. The combination air temperature and the presence of the moisture in the stem tissues in the various periods of season influences the photosynthesis and the expenditures for respiration and as the result to the accumulation of biomass in the walls of tracheids of annual increment in the pine tree

\section{Declarations}

Competing interests: The authors declare no competing interests.

Authors' Contributions: GF Antonova (conception, data analysis/interpretation, and manuscript writing), VV Stasova (experiment execution), GG Suvorova (con authors read and approved the final manuscript.

Funding: The work was supported, in part, by Grant № 30.24-2013 of integrated project "Living Nature" (N 01201354989 of the state registration) in Programs of fundamental research of Presidium RAN (Russian Academy of Science) and at part was carried out by Basic research project (№ 0356-2019-0025) of Siberian Branch, Russian Academy of Sciences.

\section{References}

References

1. Alam SA, Huang J-G, Start KJ, Comeau PG, Dawson A, Gea-Izqulerdo G, Aakala T, Hötta T, Vesala T, Mäkela A, Berninger F (2017) Photosynthetic Productivity on the Radial Growth of White Spruce in Western Canada. Front Plant Sci 8:1915. DOI: 10.3389/fpls.2017.01915

2. Acosta M, Pavelka M, Pokorny R, Janous D, Marek MV (2008) Seasonal Variation in CO2 Efflux of Stems and Branches of Norway Spruce Trees. Annals of Botany 101:469-477. https//doi:10.1093/aob/mcm304

3. Antonova GF, Shebeko VV (1981) Usage of Cresyl Violet for Studying of Wood Formation. Chemistry of Wood (Russia) 4:I02-105

4. Antonova GF, Stasova VV (1990) Accumulation of biomass in tracheid walls of annual wood layer. Lesovedenie (Russia) 3:49-57

5. Antonova GF, Stasova VV (1992) Development of annual layer in stem wood of Pinus Sylvestris L. and Larix sibirica L. Lesovedenie (Russia) 5:19-27

6. Antonova GF, Stasova VV (1993) Effects of environmental factors on wood formation in Scots pine stems. Trees 7:214-219. https://doi.org/10.1007/BF00202076

7. Antonova GF, Stasova VV (1997) Effects of environmental factors on wood formation in larch (Larix sibirica Ldb.) stem. Trees 11:462-468. https://doi.org/10.1007/PL00009687 
8. Antonova GF, Stasova VV (2015) Seasonal distribution of processes for radial diameter and wall thickness of Scots pine tracheids. Siberian Journal of Forest Science 2:33-40. doi:10.15372/SJFS20150203

9. Antonova GF, Stasova VV, Suvorova GG, Oskolkov VA (2017) Annual ring formation in Scots pine stems as the reaction on seasonal changes in photosynthesis and respiration. Proceedings "Global Conference on Plant Science and Molecular Biology (GPMB 2017) "Spain Valencia September 1113. 17

10. Antonova GF, Varaksina TN, Zheleznichenko TV, Bazhenov AV (2019) Changes in lignin structure during earlywood and latewood formation in Scots pine stems. Wood Science and Technology 53:927-952. https://doi.org/10.1007/s00226-019-01108-w

11. Arzac A, Rozas V, Rozenberg P, Olano J M (2018) Water availability controls Pinus pinaster xylem growth and density: A multiproxy approach along its environmental range. Agricultural and Forest Meteorology 250-251:171-180. https://doi.org/10.1016/j.agrformet.2017.12.257

12. Astrakhantseva NV, Antonova GF (2011) Morphological Changes in Structure of xylem and phloem in the Stems of Scots pine Trees with different rates growth. Proceed. Int. Conf. "Structural and functional deviations from normal plant growth and development under the influence of environmental factors", Petrozavodsk 20-24 June 2011. Petrozavodsk Karelian Researcher Center RAN Russia. 16-21

13. Balzano A, Čufar K, Battipaglia G, Merela M, Prislan P, Aronne G, De Micco V (2018) Xylogenesis reveals the genesis and ecological signal of IADFs in Pinus pinea L. and Arbutus unedo L. Ann Bot 121: 231-1242. DOI: 10.1093/aob/mcy008

14. Begum S, Nakaba S, Oribe Y, Kubo T, Funada R (2010) Changes in the localization and levels of starch and lipids in cambium and phloem during cambial reactivation by artificial heating of main stems of Cryptomeria japonica trees. Ann Bot 106:885-895. doi:10.1093/aob/mcq185

15. Begum S, Nakaba S, Yamagishi Y, Oribe Y, Funada R (2013) Regulation of cambial activity in relation to environmental conditions: Understanding the role of temperature in wood formation of trees. Physiol Plantarum 147:46-54. https://doi.org/10.1111/j.1399-3054.2012.01663.x

16. Bolondincki VK, Kaybijanen LK (2003) Dynamics of photosynthesis in pine standing timber. Plant Physiol (Russia) 50:105-114

17. Cabon A, Fernández-de-Uña L, Gea-Izquierdo G, Meinzer FC, Woodruff DR, Martínez-Vilalta J, De Cáceres M (2020) Water potential control of turgor-driven tracheid enlargement in Scots pine at its xeric distribution edge. New Phytol 225:209-221.DOI: 10.1111/nph.16146

18. Carr DJ (1976) Plasmodesmata in growth and development. In: Gunning BES, Robards AW (Eds.). Intercellular communication in plants: studies on plasmodesmata. Berlin, Springer, pp. 243-290

19. Chan T, Berninger F, Kolari P, Nikinmaa E, Hölttä T (2018) Linking stem growth respiration to the seasonal course of stem growth and GPP of Scots pine. Tree Physio/ 38 (9):1356-1370. https://doi:10.1093/treephys/tpy040

20. Cosgrove DJ (1997) Relaxation in a high-stress environment: the molecular bases of extensible cell walls and cell enlargement. Plant Cell 9:1031-1041

21. Cuny HE, Rathgeber CBK, Frank D, Fonti P et al. (2015) Woody biomass production lags stem-girth increase by over one month in coniferous forests. LETTERS, NATURE PLANTS. N 15160. https://doi.org/10.1038/nplants.2015.160

22. Gamalei YuV, Pakhomova MV, Syutkina AV (1996) Regulation of assimilate translocation by plasmodesmata: effect of temperature and water stress. In: Lucas, W., Zichron-Yakov (Eds), Basic and applied research in plasmodesmatal biology. Israel, pp. 132-134

23. Gifford RM (2003) Plant respiration in productivity models: conceptualisation, representation and issues for global terrestrial carbon-cycle research. Func Plant Biol. 30:171-186. DOI: 10.1071/FP02083

24. Gordon JC, Larson PR (1968) Seasonal Course of Photosynthesis, Respiration, and Distribution of ${ }^{14} \mathrm{C}$ in Young Pinus resinosa Trees as Related to Wood Formation. Plant Physiol 43:1617-1624

25. Gričar J, Čufar K (2008) Seasonal dynamics of phloem and xylem formation in silver fir and Norway spruce as affected by drought. Russ J Plant Physiol 55:538-543. DOI: 10.1134/S102144370804016X

26. Grozdits GA, Ifju G (1984) Differentiation of tracheid in developing secondary xylem of Tsuga canadensis (L.) Carr. Changes in morphology and cell wall structure. Wood Fiber Sci 16: 20-36

27. Gruber AJ, Wieser G, Oberhuber W (2009) Intra-annual dynamics of stem CO2 efflux in relation to cambial activity and xylem development in Pinus cembra. Tree Physiology 29(5):641-649. DOI:10.1093/treephys/tpp001

28. Denne M (1970) Xylem development in conifers. In: Proceed of symposium “Physiology of tree crops", 25-26 March 1969. Bristol, L, NY Acad. Press, pp 83-97

29. Deslauriers A, Morin H (2005) Intra-annual tracheid production in balsam fir stems and the effect of meteorological variables. Trees 19:402-408. DOI: 10.1007/s00468-004-0398-8

30. Deslauriers A, Beaulieu M, Balducci L, Giovannelli A, Gagnon M J, Rossi S (2014) Impact of warming and drought on carbon balance related to wood formation in black spruce. Ann Bot 114:335-345. doi: 10.1093/aob/mcu111

31. Fajstavr M, Giagli K, Vavrčík H, Gryc V, Horáček P, Urban J (2020) The cambial response of Scots pine trees to girdling and water stress. IAWA Journal 51(4):1-27. https://doi.org/10.14214/sf.1760

32. Kaybijanen LK, Sazonova TA, Tithove PV (1981) Transpiration flows in the xylem of pine tree and the dynamics of the consumption of the moisture. Lesovedenie (Russia) 2:27-34

33. Lavigne MB, Little CHA, Ridin RT (2004) Changes in stem respiration rate during cambial reactivation can be used to refine estimates of growth and maintenance respiration. New Phytol 162:81-93 https://doi.org/10.1111/j.1469-8137.2004.01004.x

34. Maier CA, Zarnoch SJ, Dougherty PM (1998) Effects of temperature and tissue nitrogen on dormant season stem and branch maintenance respiration in a young loblolly pine (Pinus taeda) plantation. Tree Physiol 18:11-20. doi: 10.1093/treephys/18.1.11

35. Mahmood A (1971) Number of initial division as a measure of activity in the early cambial growth in Pinus. Pak J For 21(1):27-42 
36. Mäkelä A, Valentine HT (2001) The ratio of NPP to GPP: evidence of change over the course of stand development. Tree Physiol 21:1015-1030. https://www.researchgate.net/publication/11786808

37. McDowell NG (2011) Mechanisms linking drought, hydraulics, carbon metabolism, and vegetation mortality. Plant Physiol155:1051-1059. https://doi.org/10.1104/pp.110.170704

38. Miller TW, Stangler DF, Larysch E, Seifert T, Spiecker H, Kahle HP (2020) Plasticity of seasonal xylem and phloem production of Norway spruce along an elevational gradient. Trees 24:43-52. https://doi.org/10.1007/s00468-020-01997-6

39. Molchanov AG (2000) Photosynthetic utilization efficiency of absorbed photo synthetically action radiation by Scots pine and birch forest stands in the southern Taiga. Tree Physiol 20:1137-1148

40. Molchanov AG, Tatarinov FA, Kurbatova YuA (2011) Emission of CO2 by Stems of Live trees, Dead Wood, and Slash in Spruce Forests in the Southwestern Valdai Upland. Lesovedenie (Russia) 3:14-25

41. Nonami H, Boyer JS (1990) Primary events regulating stem growth at low water potentials. Plant Physiol. 93:1601-1609. doi: 10.1104/pp.93.4.1601

42. Qaderi MM, Martel AB, Dixon SL (2019) Environmental Factors Influence Plant Vascular System and Water Regulation. Plants 8(3):65 https://doi.org/10.3390/plants8030065

43. Oberhuber W, Kofler W, Schuster R, Wieser G (2015) Environmental effects on stem water deficit in co-occurring conifers exposed to soil dryness. Int J Biometeorol 59:417-426. DOI 10.1007/s00484-014-0853-1

44. Rossi S, Deslauriers A, Anfodillo T (2007) Evidence of threshold temperatures for xylogenesis in conifers at high altitudes. Oecologia 152(1):1-12. DOI: 10.1007/s00442-006-0625-7

45. Rossi S, Deslauriers A, Griçar J, Seo J-W, Rathgeber CBK, Anfodillo T, Morin H, Levanic T, Oven P, Jalkanen R (2008) Critical temperatures for xylogenesis in conifers of cold climates. Glob Ecol Biogeogr 17:696-707. https://doi.org/10.1111/j.1466-8238.2008.00417.x

46. Ryan MG (1990) Growth and maintenance respiration in stems of Pinus contorta and Picea engelmannii. Can J For Res 20:48-57. D0I: 10.1139/x90-008

47. Ryan MG, Waring RH (1992) Maintenance respiration and stand development in a subalpine lodgepole pine forest. Ecology 73:2100-2108. DOI: $10.2307 / 1941458$

48. Ryan MG, Gower ST, Hubbard RM, Waring RH, Gholz HL, Wendell P, Cropper WP, Running SW (1995) Woody tissue maintenance respiration of four conifers in contrasting climates. Oecologia 101:133-140. doi: 10.1007/BF00317276

49. Ryan MG, Hubbard RM, Pongracic S, Raison RJ, McMurtrie RE (1996) Foliage, fine-root, woody-tissue and stand respiration in Pinus radiata in relation to nitrogen status. Tree Physiol 16:333-343. DOI: 10.1093/treephys/16.3.333

50. Ryan MG (2011) Temperature and tree growth. Tree Physiol 30:667-668. doi:10.1093/treephys/tpq033

51. Sauter JJ, Van Cleve R (1994) Storage, mobilization and interrelation of starch, sugars, protein and fat in the ray storage tissue of poplar trees. Trees: Structure and Function 8(6):297-304

52. Savage JA, Clearwater MJ, Haines, DF, Klein T, Mencuccini M, Sevanto S, Turgeon R, Zhang C (2016) Allocation, stress tolerance and carbon transport in plants: How does phloem physiology affect plant ecology? Plant Cell Env 39:709-725. doi: 10.1111/pce.12602

53. Seo JW, Eckstein D, Jalkanen R, Rickebusch S, Schmitt U (2008) Estimating the onset of cambial activity in Scots pine in northern Finland by means of the heat-sum approach. Tree Physiol 28: 105-112. https://doi.org/10.1093/treephys/28.1.105

54. Schulze E-D, Čermák J, Matyssek R, Penka M, Zimermann R, Vašíček F, Gries W, Kučera J (1985) Canopy transpiration and flow rate fluxes in the xylem of the trunk of Larix and Picea trees-a comparison of xylem flow, porometer and cuvette measurements. Oecologia (Berlin) 66 (4):475-483

55. Shcherbatyuk AS (1990) Multi-channel devices with CO2 gas analyzers for laboratory and field research, in: Infrared gas analyzer in the study of gas exchange plants. Moscow, Nauka, pp. 38-54.

56. Shcherbatyuk AS, Jankova LS, Rusakova LV (1990) Ecologo-physiological peculiarities of gaze exchange in conifers. Lesovedenie (Russia) 4:3-10

57. Stockfors J, Linder S (1998) Effect of nitrogen on the seasonal course of growth and maintenance respiration in stems of Norway spruce trees. Tree Physiol 18:155-166.

58. Sudachkova NE, Milyutina IL, Semenova GP (2001) Estination of accumulating functions of inner bark and wood of Larix Gmelini (Pinaceae) under low temperature and hypoxia stresses impact in rhizosphere. Bot. J. (Russia) 6(1):89-97.

59. Sun Y, Wang C, Chen HYH, Ruan H (2020) Response of Plants to Water Stress: A Meta-Analysis. Front Plant Sci. 11:978. doi: 10.3389/fpls.2020.00978

60. Suvorova GG (2009) Photosynthesis of coniferous trees under Siberian conditions. Novosibirsk: Acad Pub House "GEO".

61. Suvorova GG, Oskolkov VA, Stasova, VV, Antonova GF (2015) The Ratio of Growth Activity, Respiratory Costs and Photosynthetic Efficiency of Crown in Scots Pine. News of Irkutsk State University. Series "Biology. Ecology" (Russia) 11:2-12

62. Swidrak I, Gruber A, Oberhuber W (2014) Xylem and phloem phenology in co-occurring conifers exposed to drought. Trees 28:1161-1171 https://doi.org/10.1007/s00468-014-1026-X.

63. Tabakova M, Arzac A, Martínez E, Kirdyanov AV (2020) Climatic factors controlling Pinus sylvestris radial growth along a transect of increasing continentality in outhern Siberia. Dendrochronologia 62:125709. https://doi.org/10.1016/j.dendro.2020.125709

64. Tselniker YuL, Molchanov AG (2005) Net- and Gross-products ratio and $\mathrm{CO} 2$ gas exchange in high-yielding pines and birch trees. Hydrometeo Publishing house. 20:174-190

65. Williams AP, Allen C D, Macalady AK, Griffin D, Woodhouse CA, Meko DM et al. (2012) Temperature as a potent driver of regional forest drought stress and tree mortality. Nature Climate Change 3:292-297

66. Zabuga VF, Zabuga, GA (1985) Interrelationship between respiration and radial growth of the trunk in Scotch pine. Plant Physiol (Russian) $32: 718-728$ 
67. Zabuga VF, Zabuga GA (2006) Respiration of the growing shoots of Scots pine. Russian Journal of Plant Physiol 53(1):68-74

68. Zabuga VF, Zabuga GA (2014) Assessment of Scots Pine (Pinus sylvestris L.) Respiration at Culmination Stage of Its Current Growth in Forest_Steppe Zone of Pre_Baikal Area. Contemporary Problems of Ecology, 7 (1), 72-83

69. Zagirova SV, Kuzin SN (1998) Cambial activity and CO2 exchange in Pinus sylvestris trunk. Russian J Plant Physiol 45:735-740

70. Zha T, Kellomäki S, Wang K, Ryyppö A, Niinistö S (2004) Seasonal and annual stem respiration of Scots pine trees under boreal conditions. Annals of Botany 94:889-896

\section{Figures}

Fig. 1
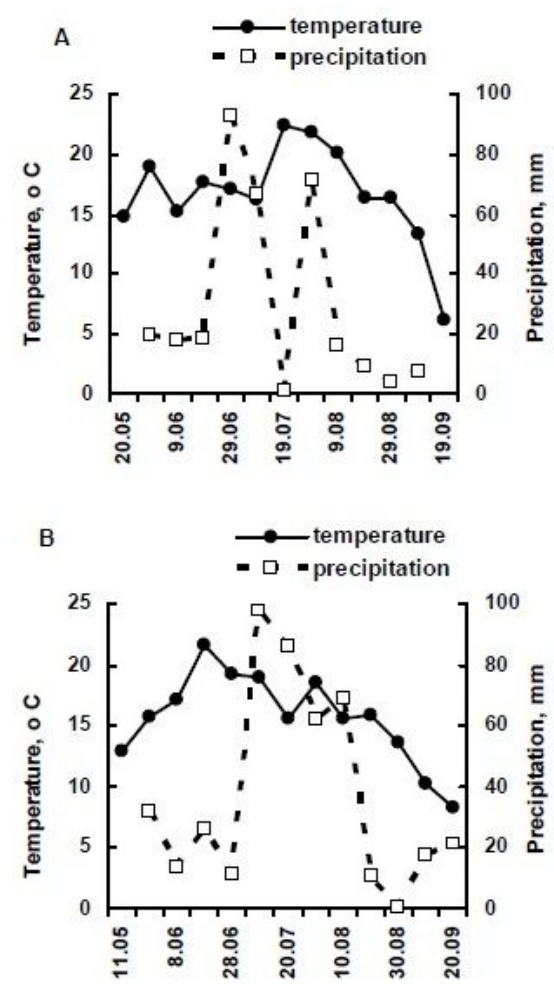

Figure 1

The changes in temperature and precipitation in separate periods of 1999 (A) and 2001 (B) years The cambial activity, assessed by the number of cambial initial cell division into the side of xylem and/or phloem, and biomass accumulation, evaluated by the increment of cell wall cross-section area, in 2001 year are shown in Fig. 2.

Fig 2

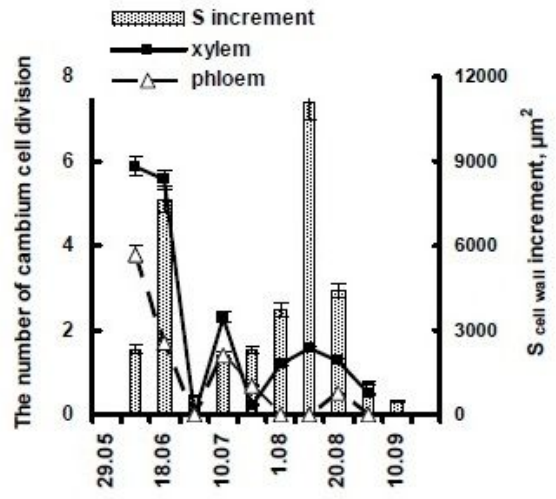

Figure 2

The dynamics of cambial activity as the number of cambium initial cell division into the side of xylem and/or phloem and of the increment of cell wall crosssection area (S increment) in the separate periods of 2001 year 
Fig 3

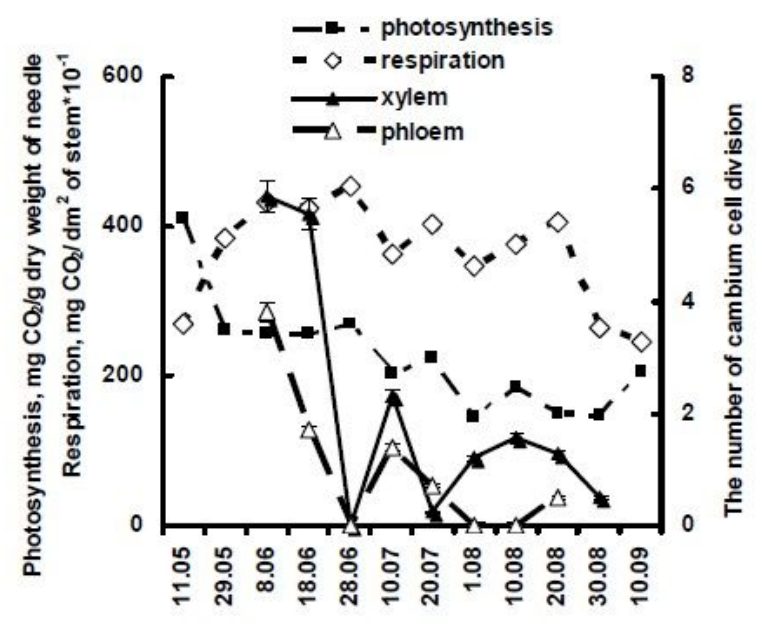

Figure 3

The dynamics of cambial activity as the number of initial cell divisions into the sides of phloem and/or xylem and the changes in photosynthesis and total respiration in separate periods of 2001 year

Fig 4
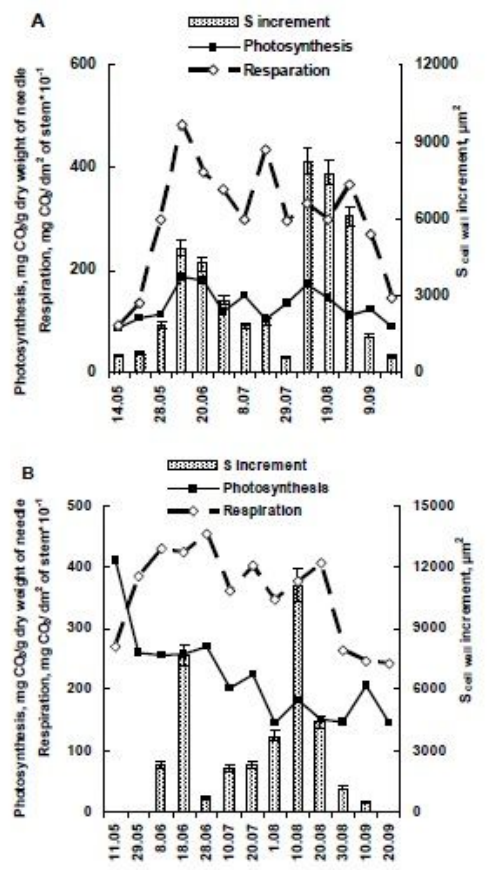

Figure 4

Seasonal dynamics of biomass accumulation in tracheid walls (Increment of S cell wall), of photosynthesis activity and total respiration in separate periods of $1999(A)$ and 2001 (B) years 
Fig. 5
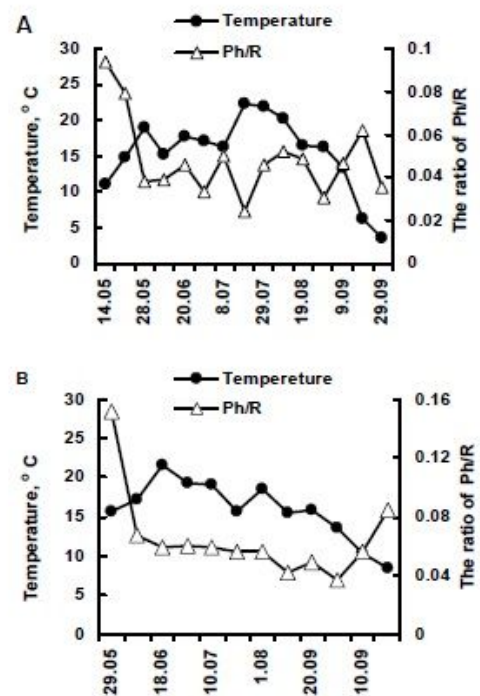

Figure 5

Effect of temperature (average on the period) on the ratio of photosynthesis/respiration (Ph/R) in separate periods of 1999 (A) and 2001 (B) years

Fig. 6
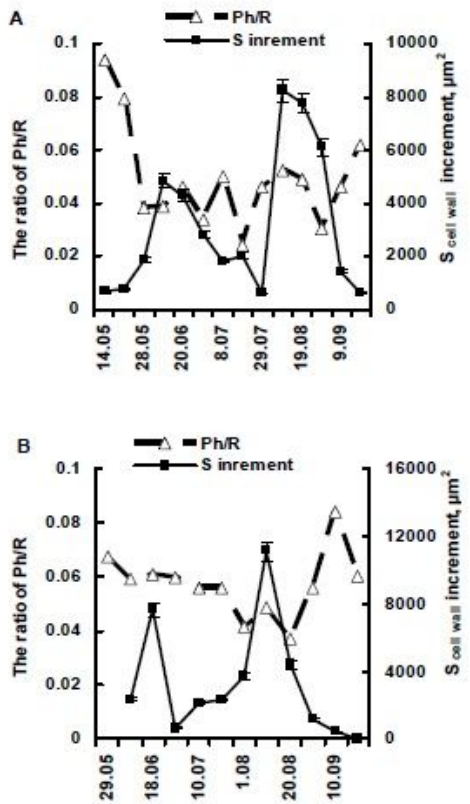

Figure 6

The changes in the ratio of photosynthesis/respiration $(\mathrm{Ph} / \mathrm{R})$ and in the increment of tracheid cell wall area (S increment) during separate periods of 1999 ( $\mathrm{A})$ and 2001 (B) years 
Fig. 7
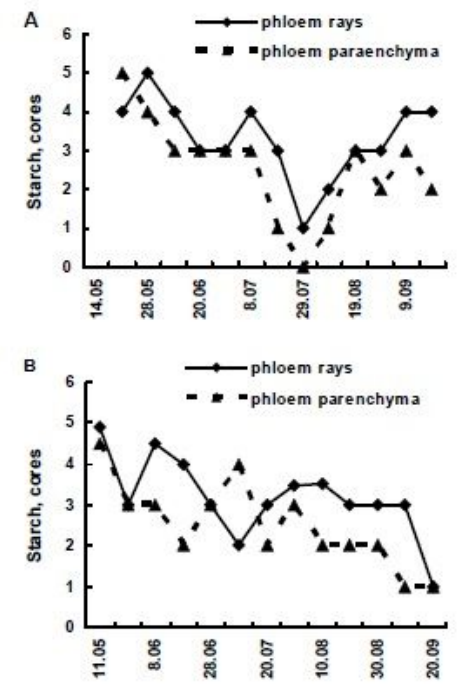

Figure 7

Changes in starch content (cores) in the rays and axial parenchyma of phloem during separate periods of 1999 (A) and 2001 (B) years

\section{Supplementary Files}

This is a list of supplementary files associated with this preprint. Click to download.

- Supplementaryfiles.doc 